\title{
Effect of Weather Parameters on Population Fluctuation of Sucking Pests and their Predators on Okra Crop
}

\author{
Babita Bhatt*, Gouri Shankar Giri, A.K. Karnatak and Shivashankara \\ Department of Entomology, G. B. Pant University of Agriculture and Technology, \\ Pantnagar - 263 145, Uttarakhand, India \\ *Corresponding author
}

\section{A B S T R A C T}

\begin{tabular}{|c|}
\hline Keywords \\
\hline $\begin{array}{l}\text { Correlation, } \\
\text { Weather } \\
\text { parameters, Sucking } \\
\text { pests, Predators, } \\
\text { okra }\end{array}$ \\
\hline Article Info \\
\hline $\begin{array}{l}\text { Accepted: } \\
\text { 06 August } 2018 \\
\text { Available Online: } \\
\text { 10 September } 2018\end{array}$ \\
\hline
\end{tabular}

\section{Introduction}

Okra Abelmoschus esculentus L. (Moench) is the most popular and commercially grown vegetable crop in India. It is a short duration crop grown throughout India. It is an important cash crop providing a good source of income and livelihood to the farmers.

In India total area and production under okra was reported to be 530.8 thousand hectare and 63.50 lakh tonnes during the year 2012-13 (Anonymous, 2013). In Uttarakhand, okra occupies 3.3 thousand hectare area with a production 26.7 thousand tonne (Anonymous, 2016).

Okra has high nutritional, industrial and medicinal values (Nadkarni, 1927 and Chauhan, 1972). It is the rich source of vitamins, minerals like $\mathrm{Fe}, \mathrm{Mn}, \mathrm{Zn}, \mathrm{Ni}$ (Bhatt et al., 2018). Medicinally, okra is useful in spermatorrhoea, genito-urinary disorder and chronic dysentery. It also cures ulcers and provides relief from hemorrhoids. The composition of okra pods per $100 \mathrm{~g}$ edible portion is: energy $144.00 \mathrm{~kJ}$ (36 kcal), water $88.6 \mathrm{~g}$, protein $2.10 \mathrm{~g}$, fat $0.20 \mathrm{~g}$, carbohydrate 
$8.20 \mathrm{~g}$, fiber $1.70 \mathrm{~g}, \mathrm{Ca} 84.00 \mathrm{mg}, \mathrm{P} 90.00 \mathrm{mg}$, Fe $1.20 \mathrm{mg}, \beta$-carotene $185.00 \mu \mathrm{g}$, riboflavin $0.08 \mathrm{mg}$, niacin $0.60 \mathrm{mg}$, thiamin $0.04 \mathrm{mg}$ and ascorbic acid $47.00 \mathrm{mg}$ (Gemede et al., 2014).

Insect pests constitute an important constraint in the successful cultivation of the crop (Bhatt and Karnatak, 2018). The yield of okra is drastically hampered by the attack of various pests like shoot and fruit borer, American bollworm or fruit borer, whitefly, leafhopper, aphids, leaf roller, blister beetle, dusky cotton bug, red spider mite etc. (Kumar et al., 2002). The key insect-pests causing the economic losses in okra are: leaf hopper, fruit borer, whitefly, thrips and shoot and fruit borer (Solangi and Lohar, 2007).

The control of pest population by biological agents is an ecofriendly pest management strategy. Some of the biological agents or predators found in okra agro-ecosystem are ladybird beetle (Coccinella spp.), green lacewing (Chrysoperla carnea), Eocanthecona spp., spiders, reduviid bug, etc. Among all the coleopteran predators Coccinella septempunctata and Chelomenes sexmaculata are the most widespread biological control agents since, they are effective against the soft-bodied insects like whitefly, leafhopper, aphids and the lepidopteran larvae (Singh et al., 2013). Spiders also play a prominent role in minimizing the pest population (Khuhro et al., 2013). However, the level of infestation and the losses caused by these pests vary from region to region as well as the season in which the crop is grown. Broadly, their infestation depends upon the environmental conditions i.e. temperature, rainfall, wind speed and relative humidity either positively or negatively.

The present study was conducted to study the relation between the weather parameters and the pest population. Thus, the knowledge of an impact of weather parameters in the sucking pest and their predator population will help in devising an effective pest management strategy.

\section{Materials and Methods}

The present investigation was carried out at the Vegetable Research Centre, GBPUAT, Pantnagar, Udham Singh Nagar (Uttarakhand) during the kharif season, 2016. Arka Anamika variety of okra was sown on 30 ${ }^{\text {th }}$ July, 2016. The experiment was laid out in a Randomized Block Design (RBD) in four replications. The plot size was $5 \times 4 \mathrm{~m}^{2}$. The row to row and plant to plant spacing was $60 \mathrm{~cm}$ and $40 \mathrm{~cm}$ respectively. Each plot consisted of six rows with eleven plants in each row. All the agronomic practices recommended to raise the okra crop were followed uniformly in each experimental plot. The observations were initiated at the seedling emergence of the crop and were continued till the final harvesting of the crop. The data was recorded at the morning hours (7-10 am) since the winged insects at that time were sluggish hence, were easily countable. The observations were taken at the weekly intervals. The sucking pest complex were visually recorded by In situ counts on three randomly selected leaves viz. each from upper, middle, and lower portion of plant randomly on five plants excluding the border rows from each plot till the final harvesting. To study predator population five plants were randomly selected and the number of predator viz. coccinellids and spiders per plant were recorded weekly. The data collected on the sucking pests and their predators was correlated with the weather parameters following standard meteorological week (SMW).

\section{Results and Discussion}

The results obtained during the course of study for the population fluctuation of pests and their predators and their correlation with 
weather parameters viz. temperature (maximum and minimum), relative humidity, wind velocity, rainfall and sunshine hours has been summarized in table 1 .

\section{Population fluctuation of sucking pests}

Leafhopper (Amrasca bigutullabigu tulla Ishida) first appeared in the field with an average population of $1.31 / 3$ leaves in the $34^{\text {th }}$ SMW. The buildup of leafhopper population was in a gradual manner and it attained its peak (11.13 / 3 leaf) in the $40^{\text {th }}$ SMW ( $1^{\text {st }}$ week of October) when the maximum and minimum temperature, morning and evening relative humidity, wind velocity and sunshine hours was $32.5^{\circ} \mathrm{C}$, $24.9^{\circ} \mathrm{C}, 88 \%$ (morning), 66\% (evening), 2.5 $\mathrm{km} / \mathrm{hr}, 3.1 \mathrm{hrs}$ and the rainfall was recorded in traces. Thereafter, there was a subsequent decrease in its population. The above findings are in accordance with Kumar et al., (2017) who while carrying out the experiment on kharif okra also recorded the first incidence of leafhopper at 21 DAS (3 weeks old crop) attaining the peak population at tenth week after the sowing and it was found till the crop was harvested. Anitha and Nandihalli (2008) also reported the first appearance of leafhopper in the first week of August $\left(34^{\text {th }}\right.$ SMW) and the maximum population was observed during the first week of October $\left(40^{\text {th }}\right.$ SMW). Whitefly (Bemisia tabaci Gennadius) first appeared in the field with an average population of $1.20 / 3$ leaves in the $34^{\text {th }}$ SMW. The buildup of whitefly population was in a gradual manner and it attained its peak (12/ 3 leaves in the $40^{\text {th }}$ SMW ( $1^{\text {st }}$ week of October) when the maximum and minimum temperature, morning and evening relative humidity, wind velocity and sunshine hours was $32.5^{0} \mathrm{C}, 24.9^{0} \mathrm{C}, 88 \%$ (morning), $66 \%$ (evening), $2.5 \mathrm{~km} / \mathrm{hr}, 3.1 \mathrm{hrs}$ and the rainfall was recorded in traces. The results of present study coincide with the findings of Anitha and Nandihalli (2008) who reported the first occurrence of whitefly (6.43 whiteflies/ 3 leaf) on okra in the first week of August $\left(34^{\text {th }}\right.$ SMW) and it remained persistent throughout the crop growing season. Selvaraj et al., (2010) also noticed the peak incidence of whitefly from mid-August to mid-October. Aphids (Aphis gossypii Glover) first appeared in the field with an average population of 5.14 / 3 leaves in the $35^{\text {th }}$ SMW. It attained its peak (23.08 / 3 leaves) in the $39^{\text {th }}$ SMW (last week of September) when the maximum and minimum temperature, morning and evening relative humidity, wind velocity and sunshine hours were $32.2^{\circ} \mathrm{C}, 23.2^{\circ} \mathrm{C}, 87 \%$ (morning), $62 \%$ (evening), $2.9 \mathrm{~km} / \mathrm{hr}, 8.8 \mathrm{hrs}$ and the rainfall was recorded to be $3.4 \mathrm{~mm}$. These findings collaborate with the observations of Singh et al., (2013) who noticed the first population of aphids on okra on the $35^{\text {th }}$ SMW, 35 DAS with an average aphid population of 1.42 aphids per leaf that increased in due course of time and reached to its maximum of 25.87 per leaf during the $40^{\text {th }}$ SMW in the first week of October, thereafter following a considerable decrease in its population (1.00 aphids/ plant) in $47^{\text {th }} \mathrm{SMW}$. Konar et al., (2013) reported the peak population of aphids in the first week of September (39.28 aphids/ 3 leaves) on okra.

\section{Population fluctuation of predators}

Among the predators population the spiders and coccinellids first appeared in the field with an average population of 0.33 spider/ plant and 0.22 coccinellal plant in the $33^{\text {rd }}$ and $34^{\text {th }} \mathrm{SMW}$, respectively. The population of spider and coccinella attained their peak (3.16 spider/ plant and 3.01 coccinella/ plant) in the $39^{\text {th }}$ SMW (last week of September) when the maximum and minimum temperature, morning and evening relative humidity, wind velocity and sunshine hours were $32.2^{0} \mathrm{C}$, $23.2^{0} \mathrm{C}, 87 \%$ (morning), 62\% (evening), 2.9 $\mathrm{km} / \mathrm{hr}, 8.8 \mathrm{hrs}$ and the rainfall was recorded to be $3.4 \mathrm{~mm}$. 
Table.1 Population fluctuation of pests and their predators with weather parameters at VRC, Pantnagar, during kharif, 2016

\begin{tabular}{|c|c|c|c|c|c|c|c|c|c|c|c|c|c|c|}
\hline \multirow[t]{2}{*}{ Month } & \multirow[t]{2}{*}{ Date } & \multirow[t]{2}{*}{ SMW } & \multicolumn{2}{|c|}{$\begin{array}{c}\text { Temperature } \\
\left({ }^{0} \mathrm{C}\right)\end{array}$} & \multicolumn{2}{|c|}{ Relative Humidity (\%) } & \multirow[t]{2}{*}{$\begin{array}{l}\text { Rainfall } \\
(\mathbf{m m})\end{array}$} & \multirow{2}{*}{$\begin{array}{c}\text { Sun- } \\
\text { shine } \\
\text { Hrs. }\end{array}$} & \multirow{2}{*}{$\begin{array}{l}\text { Wind } \\
\text { Velocity } \\
(\mathrm{km} / \mathrm{hr})\end{array}$} & \multirow{2}{*}{$\begin{array}{c}\text { Leafhopper } \\
\text { population } \\
\text { /3 leaves }\end{array}$} & \multirow{2}{*}{$\begin{array}{c}\text { Whitefly } \\
\text { population/3 } \\
\text { leaves }\end{array}$} & \multirow{2}{*}{$\begin{array}{c}\text { Aphids } \\
\text { population/3 } \\
\text { leaves }\end{array}$} & \multirow[t]{2}{*}{$\begin{array}{c}\text { Spiders/ } \\
\text { plant }\end{array}$} & \multirow[t]{2}{*}{$\begin{array}{l}\text { Coccinellids/ } \\
\text { Plant }\end{array}$} \\
\hline & & & Max. & Min. & Morning & Evening & & & & & & & & \\
\hline $\begin{array}{l}\text { July- } \\
\text { Aug }\end{array}$ & $30-05$ & 31 & 32.7 & 25.7 & 86 & 69 & 123.0 & 6.4 & 6.3 & 0 & 0 & 0 & 0 & 0 \\
\hline Aug & $06-12$ & 32 & 32.6 & 26.3 & 89 & 70 & 40.2 & 6.0 & 6.5 & 0 & 0 & 0 & 0 & 0 \\
\hline Aug & 13-19 & 33 & 33.0 & 25.9 & 93 & 69 & 102.0 & 4.0 & 4.2 & 0 & 0 & 0 & 0.33 & 0 \\
\hline Aug & $20-26$ & 34 & 33.3 & 26.3 & 87 & 67 & 1.0 & 8.1 & 4.7 & 1.31 & 1.2 & 0 & 0.52 & 0.22 \\
\hline $\begin{array}{l}\text { Aug- } \\
\text { Sep }\end{array}$ & $27-02$ & 35 & 33.7 & 25.5 & 89 & 65 & 26.6 & 5.9 & 4.5 & 4.9 & 2.23 & 5.14 & 0.98 & 0.47 \\
\hline Sep & 03-09 & 36 & 32.7 & 25.3 & 91 & 68 & 2.4 & 5.9 & 5.7 & 7.89 & 4.81 & 10.96 & 1.34 & 0.89 \\
\hline Sep & $10-16$ & 37 & 32.3 & 24.5 & 89 & 71 & 59.4 & 4.8 & 4.0 & 8.4 & 7.63 & 19.75 & 1.50 & 1.29 \\
\hline Sep & $17-23$ & 38 & 32.5 & 24.2 & 90 & 66 & 76.6 & 6.4 & 3.6 & 9.6 & 8.9 & 21.31 & 2.25 & 2.68 \\
\hline Sep & 24-30 & 39 & 32.2 & 23.2 & 87 & 62 & 3.4 & 8.8 & 2.9 & 10.21 & 10.42 & 23.08 & 3.16 & 3.01 \\
\hline Oct & 01-07 & 40 & 32.5 & 24.9 & 88 & 66 & 0.0 & 3.1 & 2.5 & 11.13 & 12.11 & 20.17 & 2.39 & 2.00 \\
\hline Oct & 08-14 & 41 & 32.1 & 19.9 & 89 & 61 & 0.0 & 7.4 & 2.7 & 8.86 & 9.62 & 11.69 & 2.07 & 1.71 \\
\hline Oct & $15-21$ & 42 & 31.4 & 17.2 & 80 & 47 & 0.0 & 7.6 & 2.2 & 8.01 & 6.54 & 5.82 & 1.25 & 0.28 \\
\hline Oct & $22-28$ & 43 & 31.1 & 13.9 & 90 & 37 & 0.0 & 7.8 & 2.3 & 6.93 & 4.38 & 3.96 & 0.36 & 0 \\
\hline
\end{tabular}

Table. 2 Correlation coefficient of pests and their predator population with weather parameters

\begin{tabular}{|c|c|c|c|c|c|c|c|}
\hline \multirow[t]{2}{*}{ Pests/Predators } & \multicolumn{2}{|c|}{ Temperature $\left({ }^{0} \mathrm{C}\right)$} & \multicolumn{2}{|c|}{ Relative Humidity (\%) } & \multirow{2}{*}{$\begin{array}{l}\text { Rainfall } \\
(\mathrm{mm})\end{array}$} & \multirow[t]{2}{*}{ Sunshine (hrs) } & \multirow{2}{*}{$\begin{array}{l}\text { Wind Velocity } \\
(\mathrm{km} / \mathrm{hr})\end{array}$} \\
\hline & Max. & Min. & Morning & Evening & & & \\
\hline Leafhopper & -0.453 & -0.397 & -.132 & -.293 & -.531 & .051 & $-.711^{* *}$ \\
\hline Whitefly & -0.419 & -0.297 & -.152 & -.167 & -.456 & .002 & $-.718^{* *}$ \\
\hline Aphids & -0.204 & 0.342 & 0.038 & 0.106 & -0.218 & -0.096 & -0.474 \\
\hline Spiders & -0.170 & -0.071 & -0.086 & 0.027 & -0.390 & 0.078 & $-0.582 *$ \\
\hline Coccinellids & -0.108 & 0.044 & 0.013 & 0.0152 & -0.307 & 0.060 & -0.455 \\
\hline
\end{tabular}

*Significant at 0.05 level; **Significant at 0.01 level; Min.: Minimum temperature; Max.: Maximum temperature

The current study is in confirmation with the work of Ghosh (2013) who observed the maximum population of spiders during AprilMay and August-September (12-21 and 31-39 SMW, respectively) in the okra agro ecosystem. According to Singh et al., (2013) the population of aphidophagous coccinellid predators appeared simultaneously with population of soft bodied insects mainly aphids on okra.

Correlation of weather parameters with the population of sucking pests and their predators

A simple correlation was worked out between the population of sucking pests and their predators that have been indicated in Table 2 . A simple correlation was worked out between the sucking pest population and the weather parameters. There was observed a negative non-significant correlation of the leafhopper and whitefly population with all of the remaining weather parameters except that a negative significant correlation $\left(\mathrm{r}=-0.711^{*}\right.$ and $r=-0.718^{*}$ ) was observed with the wind velocity and a positive significant correlation $(r=0.051$ and $r=0.002)$ was observed with the sunshine hours. This finding is supported by the study of Dabhi and Koshiya (2014) who also found a positive correlation between the population of leafhopper and bright sunshine hours. Similar results were obtained by Verma et al., (2015) who observed the negative correlation of whitefly population with maximum as well as minimum temperature and wind speed. However, there was observed a non-significant negative 
correlation of the aphid population with maximum temperature, rainfall, sunshine hours and wind velocity. A positive correlation $(r=0.342, r=0.038, r=0.106)$ with minimum temperature, morning and evening relative humidity was also observed.

A simple correlation when worked out between the predator population and weather parameters revealed that there was a nonsignificant correlation of the spider population with all the weather parameters except with wind velocity it had a negative significant correlation $(\mathrm{r}=-0.582 *)$. In the similar manner, coccinellids population was nonsignificantly correlated with all the weather parameters. The current observation is supported by Shukla, N. (2014) who also reported a non- significant negative correlation between coccinellids and maximum temperature and a positive correlation with the morning and the evening relative humidity.

The current study deals with the fluctuation in sucking pest population and their predators along with their correlation with weather parameters. In the present study the peak population of sucking pests and their predators was attained in the month of September-October. The pests (leafhopper and whitefly) and predators population was positively correlated with sunshine hours. The findings of the present study might help the farmers of Uttarakhand to bring about the better control of the pests through natural enemies. Moreover, these findings may help to avoid the indiscriminate and injudicious use of pesticides on okra agroecosystem.

\section{References}

Anitha, K.R. and Nandihalli, B.S. 2008. Utilization of botanicals and mycopathogens in the management of sucking pests of okra. Karnataka
Journal of Agricultural Sciences. 21(2): 231-233.

Anonymous, 2013. Indian Horticulture Database 2013. pp. 152-159.

Anonymous, 2016. Horticulture Statistics Division, Department of Agriculture, Cooperation and Farmers Welfare. Ministry of Agriculture.

Bhatt, B. and Karnatak, A.K. 2018. Population dynamics of sucking pests and their predators on okra agroecosystem. Journal of Entomology and Zoology Studies. 6(2): 1289-1291.

Bhatt, B., Joshi, S. and Karnatak, A.K. 2018. Biodiversity of insect pests and their predators on okra agroecosystem. Journal of Pharmacognosy and Phytochemistry. 7(4): 84-86.

Chauhan, D.V.S. 1972.Vegetable production in India, Ram Prasad and Sons, India.

Dabhi, M.V. and Koshiya, D.J. 2014.Effect of abiotic factors on population dynamics of leafhopper, Amrasca biguttulabigut tula (Ishida) in okra. Advance Research Journal of Crop Improvement. 5(1): 1114.

Gemede, H.F., Ratta, N., Haki, G.D., Woldegiorgis, A.Z. and Beyene, F. 2014. Nutritional Quality and Health Benefits of Okra (Abelmoschus esculentus): A Review. Food Science and Quality Management, 33: 87-96.

Ghosh, S. 2013. Harmful Effect of Insecticides in the Population Dynamics of Spiders on Lady's fingers Abelmoschus esculentus (L.) Moench at Field Level. American-Eurasian Journal of Agricultural \& Environmental Sciences. 13(9): 1181-1186.

Khuhro, S.A., Sahito, H.A., Lanjar, A.G., Khuhra, S.A. and Solangi, A.W. 2013. Carnivores Spiders Fauna in Lady's Finger, Abelmoschus esculentus Vegetable Crop. Journal of Advances in Agricultural Science and Technology. 2(3): 33-37. 
Konar, A., More, K.A. and Ray, S.K.D. 2013.Population dynamics and efficacy of some insecticides against aphid on okra. Journal of Crop and Weed. 9(2): 168-171.

Kumar, P., Singh, D.V. and Sanchan, S.K. 2017. Succession of Important Insect Pests of Okra Abelmoschus esculentus Under Western Uttar Pradesh Climatic Conditions. International Journal of Engineering and Management Science. 8(1): 72-74.

Kumar, S., Prasad, S. and Singh, R.N. 2002. Resurgence of two spotted mite due to acaricides and botanicals on okra.Ann. Pl. Protect. Sci., 10: 51-54.

Nadkarni, K. M. 1927. Indian Meteria, Nadkarni and Co., Bombay, p. 104.

Pathan, N.P. and Bharpoda, T.M. 2016.Succession of major insect pests in Okra, Abelmoschus esculentus (L.) Moench grown In Summer. International Journal of Agricultural Science and Research. 6(4): 111-118.

Selvaraj, S., Adiroubane, D. and Ramesh, V. 2010.Population dynamics of important insect pests of bhindi in relation to weather parameters.Pestology.34: 3539.

Shukla, N. 2014.Seasonal Incidence and Relation to Weather Parameters of Aphid and their Natural Enemies on Okra. International Journal of Scientific and Research Publications. 4(3): 1-3.

Singh, Y., Jha, A., Verma, S., Mishra, V.K. and Singh, S.S. 2013. Population dynamics of sucking pests and its natural enemies on okra agro-ecosystem in Chitrakoot region. African Journal of Agricultural Research. 8(28): 38143819.

Solangi, B.H. and Lohar, M.K. 2007. Effect of some insecticides on the population of insect pests and some predators of okra. Asian Journal of Plant Sciences. 6(6): 920-926.

Verma, D., Mondal, P. and Sahu, M.K. 2015. To study the seasonal incidence of Jassids (Amrasca bigutullabigu tulla) and whitefly (Bemisia tabaci.) of okra with response to various abiotic factors. Journal of Plant Development Sciences. 7 (11): 803-807.

\section{How to cite this article:}

Babita Bhatt, Gouri Shankar Giri, A.K. Karnatak and Shivashankara. 2018. Effect of Weather Parameters on Population Fluctuation of Sucking Pests and Their Predators on Okra Crop. Int.J.Curr.Microbiol.App.Sci. 7(09): 757-762. doi: https://doi.org/10.20546/ijcmas.2018.709.091 